\title{
Article
}

http://dx.doi.org/10.11646/phytotaxa.233.1.3

\section{Dianthus borbonicus (Caryophyllaceae), a new species from Sicily}

\author{
SALVATORE BRULLO ${ }^{1 *}$, CRISTIAN BRULLO ${ }^{1}$, PAOLO COLOMBO ${ }^{2}$, GIANPIETRO GIUSSO DEL GALDO ${ }^{1}$, \\ VINCENZO ILARDI ${ }^{3} \&$ ROSARIA PERRONE ${ }^{2}$ \\ 1 Dipartimento di Scienze Biologiche, Geologiche e Ambientali, Università di Catania, via A. Longo 19, I 95125 Catania, Italy; \\ salvo.brullo@gmail.com \\ 2 Dipartimento di Scienze Terrestri e Marine, Divisione di Ecologia, Università di Palermo, Viale delle Scienze, Ed. 16, I-90128 \\ Palermo, Italy \\ 3 Dipartimento di Scienze della Terra e del Mare, Università di Palermo, via Archirafi 26, I 90123 Palermo, Italy \\ * Author for correspondence
}

\begin{abstract}
Dianthus borbonicus a new species occurring in North-Western Sicily is described and illustrated. It is a rare chasmophyte belonging to the $D$. sylvestris group, which is exclusive of a rupestrian stand near Rocca Busambra (Ficuzza). Its macro- and micromorphological features (seed testa sculptures, and leaf anatomy), ecology, conservation status and a comparison with the related species are provided too.
\end{abstract}

Key Words: Anatomy, Dianthus, seed testa, Sicily, taxonomy

\section{Introduction}

Dianthus Linnaeus (1753: 409) is one of the largest genera of Caryophyllaceae comprising approximately 600 species, which are widespread distributed in Europe, Asia and North Africa, while some species occur in North America and South Africa (see e.g., Ilçim et al. 2013). Owing to their ornamental properties, several taxa (species, subspecies, varieties, cultivars or hybrids) are cultivated for gardening. Concerning the native species, they mainly occur in rupestrian habitat, which are usually considered as refuge sites for ancestral plants, as well as grasslands, garigues, steppes, mesic meadows, etc. (Bacchetta et al. 2010).

An important diversity centre of the genus Dianthus, mainly regarding the Dianthus sylvestris group, is the central Mediterranean area (Sardinia, Corsica, Sicily, Italian Peninsula and Croatia) where the number of taxa is high (see e.g., Bacchetta et al. 2010).

Recent field investigations carried out in some poorly known areas of Sicily led us to discover of an unusual and quite isolated population of Dianthus, which appears to be morphologically well different from the other taxa included in the D. sylvestris group. Taxonomical investigations carried out on living plants, and anatomical analyses on the leaves and seed surface, allowed to establish that the population found can be proposed as a distinct species, named $D$. borbonicus.

\section{Materials and methods}

Morphological analyses are carried out on both herbarium material (Herbarium CAT, acronym according to Thiers 2015 continuously update) and living plants (from locus classicus) (Table 1).

Seed testa morphology was examined on mature and dried seeds by using a scanning electron microscope (SEM) Zeiss EVO LS10, according to the protocol reported by Stork et al. (1980), while terminology of the seed coat sculpturing follows Bartholot (1981) and Gontcharova et al. (2009) (see Table 1). 
TABLE 1. Herbarium specimens of Dianthus borbonicus and allied species.

\begin{tabular}{lllll}
\hline Species & Locality & Date & Collector(s) & Herbarium \\
\hline Dianthus borbonicus & Corona del Re (Pizzo Morabito) & 10 June 2014 & S. Brullo \& V. Ilardi s.n. & CAT \\
Dianthus borbonicus & Corona del Re (Pizzo Morabito) & 29 June 2011 & S. Brullo et al. s.n. & CAT \\
Dianthus minae & Passo Scuro (Castelbuono) & 29 June 2011 & S. Brullo et al. s.n. & CAT \\
$\begin{array}{l}\text { Dianthus busambrae } \\
\text { Dianthus cyathophorus }\end{array}$ & Rocca Busambra (Ficuzza) & 24 June 1999 & G. Giardina s.n. & CAT \\
Dianthus cyathophorus & Foresta Marganai (Iglesias) & 04 June 2002 & G. Bacchetta et al. s.n. & CAT \\
Dianthus arrostii & Cozzo del Pellegrino (Madonie) & 05 July 2011 & C. Brullo et al. s.n. & CAT \\
\hline
\end{tabular}

Concerning the anatomical study, the most developed leaves were considered and fixed in FAA $(90 \%$ ethanol, 5\% formalin, 5\% acetic acid) (Sass 1958), dehydrated in graded ethanol series and embedded in paraffin, following the protocol of Beccari and Mazzi (1966). Cross sections (about 10-20 $\mu \mathrm{m}$ thick) were prepared with Jung-R 2050Supercut Microtome (Reichert-Jung, Leica) and stained by Safranin; permanent slides were mounted in Canada balsam, then examined under light microscope Leica DMLS and photomicrographed by a NIKON DS Head DS-Fi1 digital camera.

\section{Taxonomic treatment}

Dianthus borbonicus Brullo, C. Brullo, Colombo, Giusso, Ilardi \& Perrone, sp. nov. (Figs.1, 2A-C).

Type:-SICILY. [Palermo] Ficuzza, Corona del Re presso Pizzo Morabito, su pareti calcaree esposte a Nord, a ca. $1150 \mathrm{~m}$ s.1.m., $37^{\circ} 50^{\prime}$ 44" N, 1326' 37" E, 10 June 2014, Brullo \& Ilardi s.n. (holotype CAT!, isotypes CAT!, FI!).

Diagnosis:-A Diantho cyathophoro differt caudice compacto, foliis basalibus 2-10(-11) cm longis, 2-4 mm latis, foliis caulinis 2-5(-6) cm longis, caule 6-25 cm longo, 1-4-floro, bracteis calycinis divaricatis vel patentibus, mucrone 0.5-2.0 mm longo, interioribus $10 \mathrm{~mm}$ longis, $12-13 \mathrm{~mm}$ latis, esterioribus $8-10 \mathrm{~mm}$ longis, $5.0-7.5 \mathrm{~mm}$ latis, calyce 26-30 mm longo, $6.0-7.5 \mathrm{~mm}$ diametro, anthera $3.5 \mathrm{~mm}$ longa.

Description (macro-morphology):-Suffrutex, 15-30(-35) cm tall; woody stocks densely branched, with branches $1-4 \mathrm{~cm}$ long. Basal leaves inserted along the woody stock branches, flat, 2-10(-11) cm long, 2-4 mm wide, acute at the apex; cauline leaves 2-5(-6) cm long. Stems 1-4-flowered, 6-25 cm long, with 4-5 internodes; epicalyx scales 4 , divaricate to patent, with mucro $0.5-2.0 \mathrm{~mm}$ long; the inner ones subrounded to obovate, $10 \mathrm{~mm} \times 12-13$ $\mathrm{mm}$, the outer ones ovate to subrounded, $8-10 \times 5.0-7.5 \mathrm{~mm}$; calyx $26-30 \mathrm{~mm}$ long, $6.0-7.5 \mathrm{~mm}$ in diameter, with teeths triangular, slightly membranaceous on the margin, acute, not overlapping, $6-7 \mathrm{~mm}$ long; petals $40-45 \mathrm{~mm}$ long, claw 25-30 mm long, limb purplish-pink, cuneate-rounded, $15.0 \times 11-14 \mathrm{~mm}$, with 20-34 teeth, 0.3-2.0 mm long, simple, triangular; anther pink-lilac, $3.5 \mathrm{~mm}$ long; ovary $8-10 \mathrm{~mm}$ long; style with stigma 20-24 mm long. Capsule cylindrical, 14-16 mm long included in the calyx.

Seed testa micro-morphology:-According to literature (e.g., Yildiz 2002, Vural 2008, Yildiz \& Güzel 2008, Ilçim et al 2013, Hamzaoğlu et al. 2015a, 2015b), the seeds of Dianthus are black, flat, peltate, cuspidate at apex, with coat made by elongate cells, which are undulate at the margins, and more or less minutely papillose. As concerns $D$. borbonicus, the seeds show a suborbicular to orbicular-ovate outline, and they are covered by irregularly elongate cells, which are loosely undulate at the margins, and have anticlinal walls represented by a deep and wide grooves, irregularly trabeculate, with U- to S-like undulations, while the periclinal walls are minutely papillose and colliculate, with one or two series of colliculi (Fig. 3A). In addition, the cells on the dorsal face are shorter than those in the centre $(75-110 \mu \mathrm{m})($ Fig. 3A2) and longer than the cells on the margins $(130-260 \mu \mathrm{m})$ (Fig. 3A3), while they are morphologically uniform in ventral portion $(60-130 \mu \mathrm{m})$ (Fig. 3A5). 


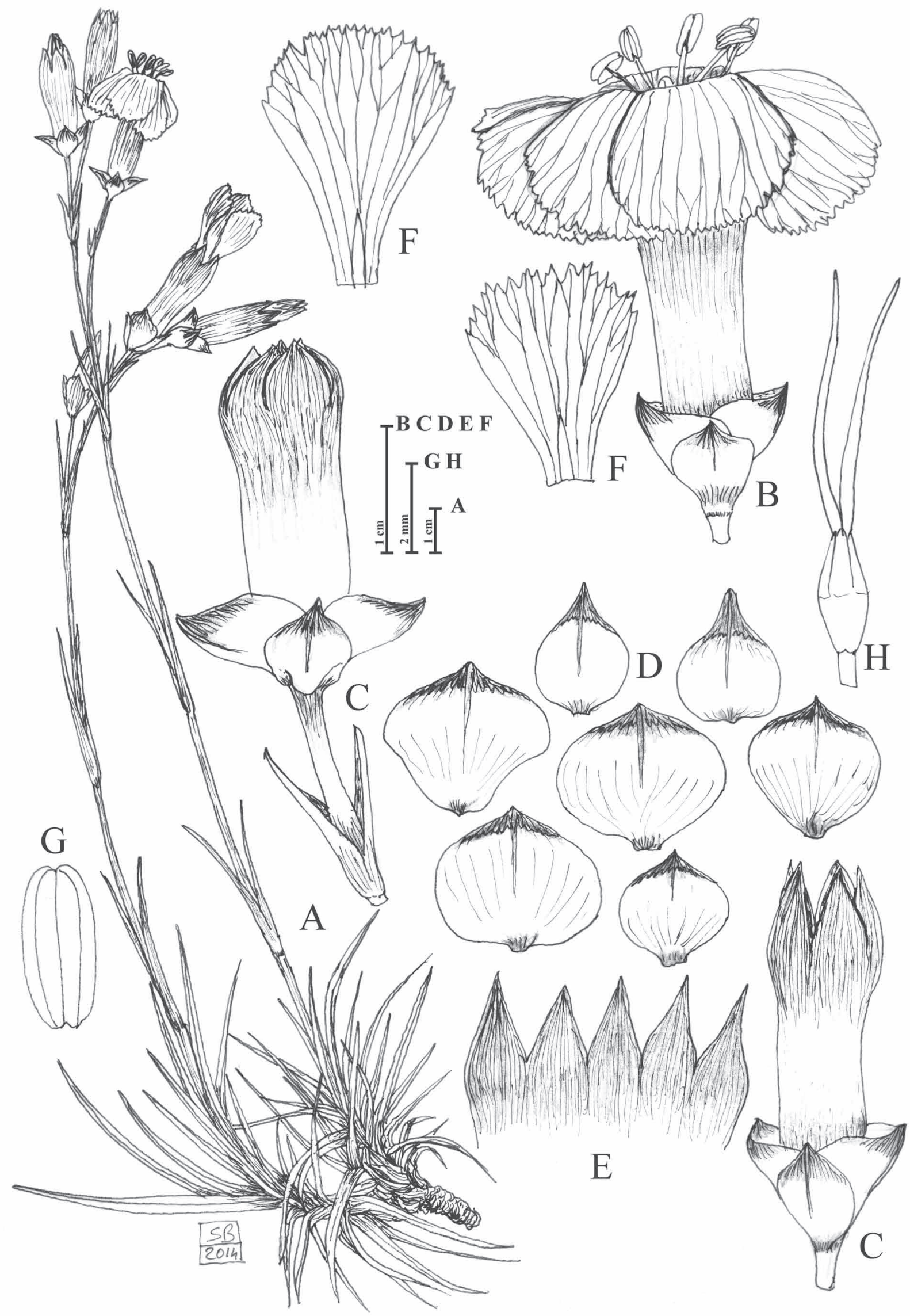

FIGURE 1. Diagnostic features of Dianthus borbonicus. A) Habit, B) Flower, C) Calyces and scales, D) Epicalyx scales, E) Calyx teeth, F) Petal limbs, G) Anther, H) Pistil (drawing by S. Brullo based on living material coming from the type locality). 

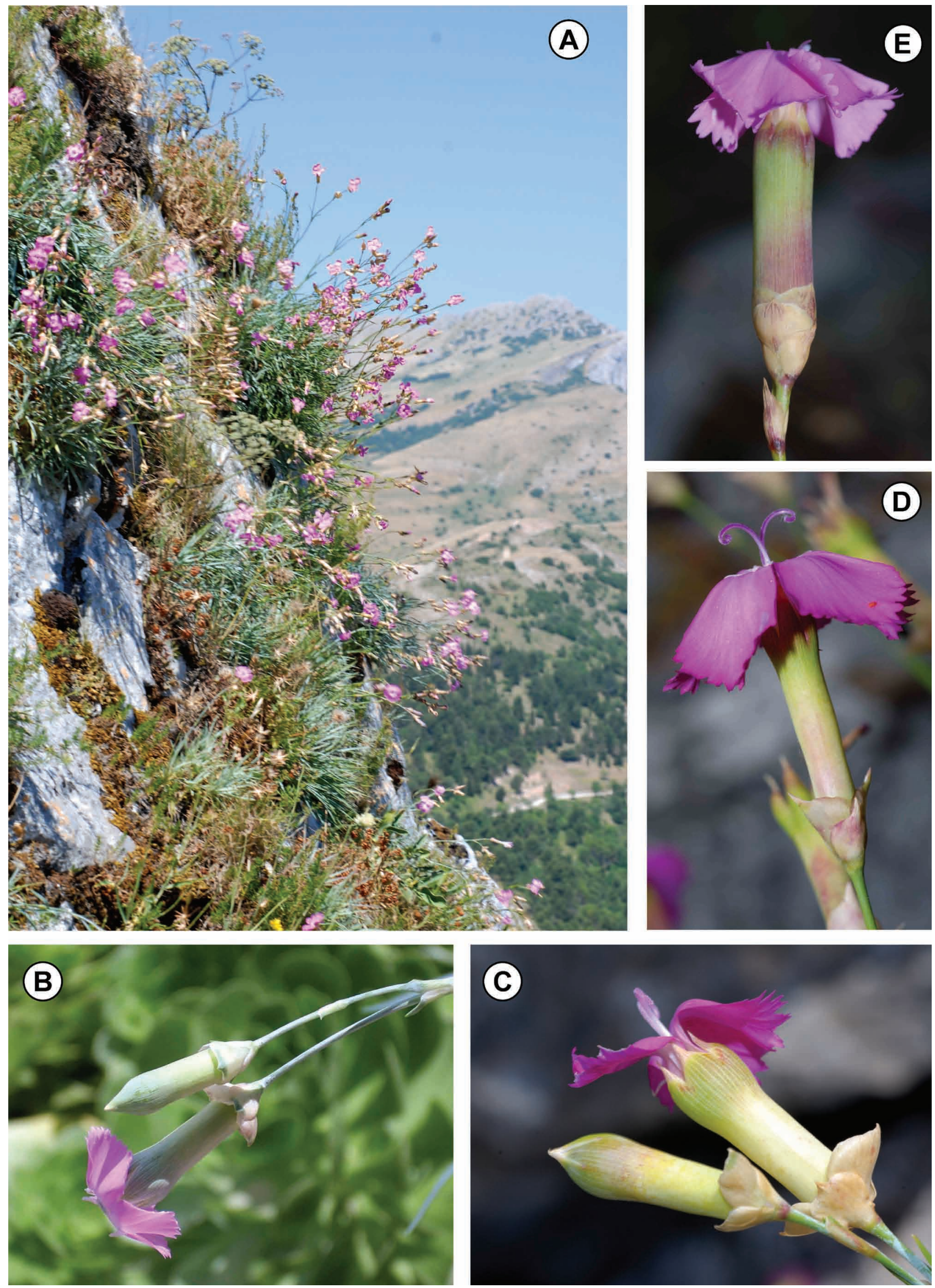

FIGURE 2. Habitat of D. borbonicus (A). Flowers of D. borbonicus (B-C), D. minae (D) and D. busambrae (E) (photos by V. Ilardi). 
The seeds of the two closely related species [D. busambrae Soldano \& F. Conti (2005: 18) and D. minae Mazzola, Raimondo \& Ilardi (2004: 307)] were examined for a comparison. Actually, they are quite similar to those ones of $D$. borbonicus (Fig. 3B), but some important differences occur. D. busambrae shows seeds ovate, with testa characterized by very irregular cells in the dorsal face, isodiametric to elongate in the cental part $(55-100 \mu \mathrm{m})$, tightly undulate at the margin, having anticlinal walls represented by a deep and narrow grooves, not trabeculate, with $\mathrm{U}$ - or $\Omega$-like undulations (Fig. 3B2), while in D. minae, the peripherical cells are elongated $(55-130 \mu \mathrm{m})$, with anticlinal walls having S- or U-like undulations (Fig. 3B3). As concerns the periclinal walls, they are very similar to those ones of $D$. busambrae, but always with one series of colliculi. Cells of the ventral face are very homogeneous, elogated $(80-150 \mu \mathrm{m})$, with anticlinal walls usually having U-like undulations (Fig. 3B5). Seeds of D. minae are, instead, ovate-lanceolate (Fig. 3C), with irregularly elongated cells in the dorsal face, shorter in the centre (75-120 $\mu \mathrm{m})$, tightly undulate at the margin (Fig. 3C2). Anticlinal walls are made by deep and very narrow grooves, not trabeculate, with V- or U-like undulations, while the periclinal walls are very similar with only one series of colliculi (Fig. 3C3). Cells of the ventral face are elongated and more or less uniform 130-200 $\mu \mathrm{m}$ ), with grooves of the anticlinal walls more spaced showing usually U-like undulations (Fig. 3C5).
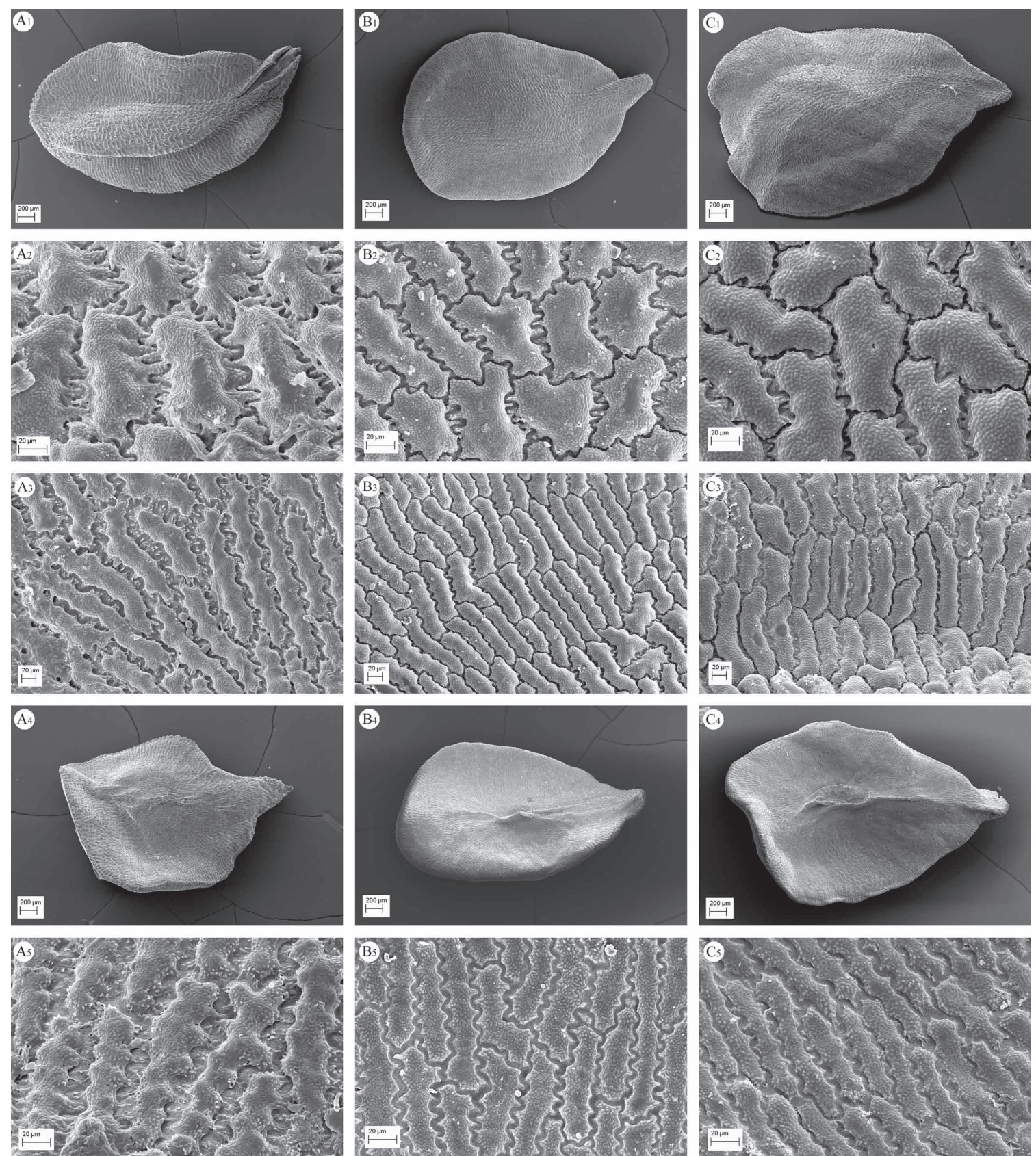

FIGURE 3. SEM micrographs of the seed coat of Dianthus borbonicus (A1-5), D. busambrae (B1-5) and D. minae (C1-5). 1. Seed (dorsal face, $\times 30$ ). 2. Seed coat (central part of dorsal face, $\times 500)$. 3. Seed coat (marginal part of dorsal face, $\times 250)$. 4. Seed $($ ventral face, $\times 30$ ). 5. Seed (ventral face, $\times 500$ ), from material coming from the type localities. 

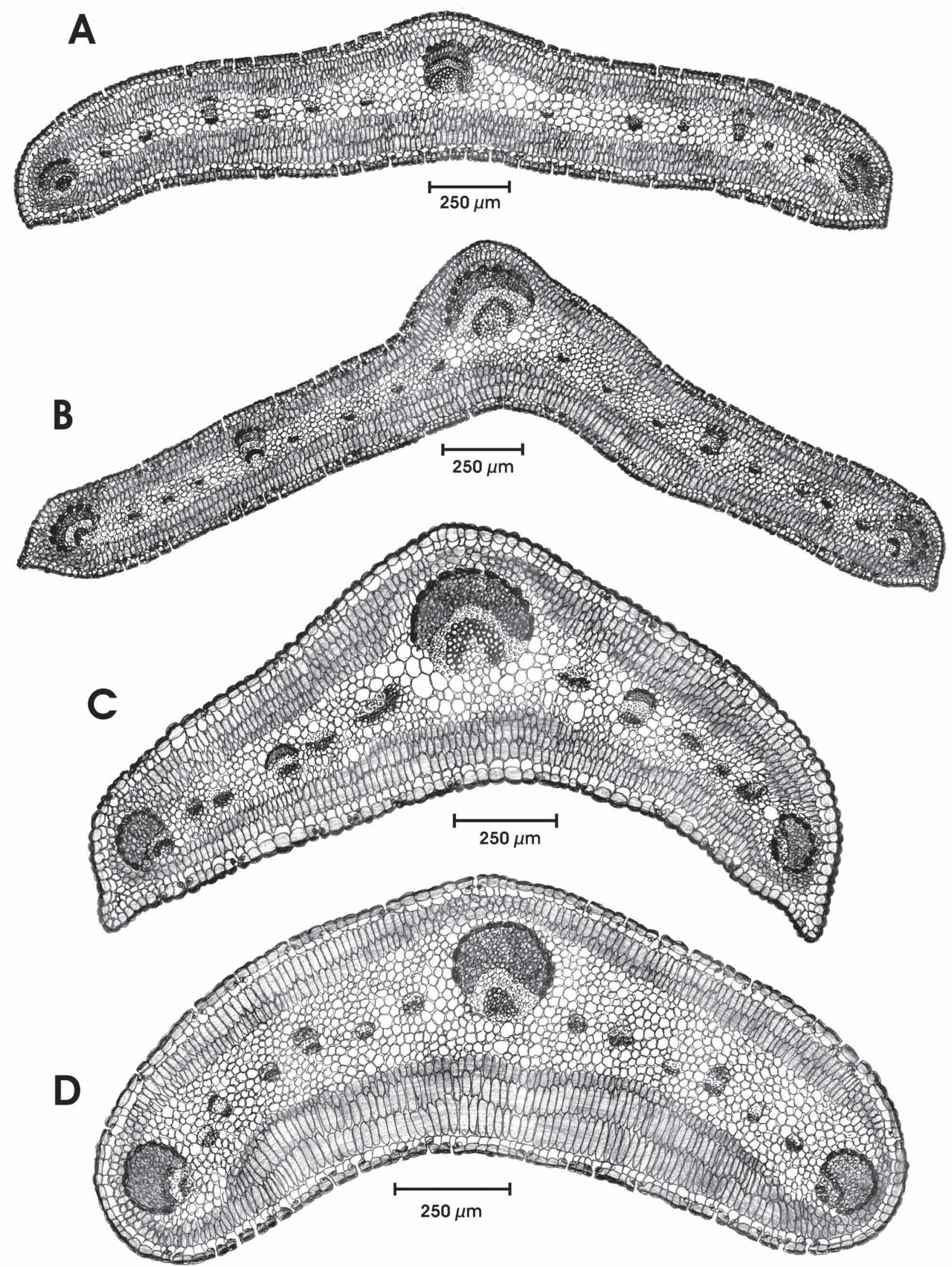

FIGURE 4. Leaf cross sections of Dianthus borbonicus (A), D. busambrae (B), D. minae (C) and D. arrosti (D) from living material coming from the type localities (CAT). 
Leaf anatomy:-Leaves in Dianthus borbonicus appear asymmetrical from the macro-morphological point of view. However, in cross section. they show the typical arrangement of the isobilateral structure (Fig. 4A). It can be considered amphistomataous, with the palisade layer distributed along the whole surface, the abaxial face differing from the adaxial one only concerning a central prominence due to the midrib. The epidermis is 1-layered with a well developed cuticle and numerous sunken stomata. The external parenchyma is represented by a palisade, usually 3-layered (sometimes 2-layered), more developed in the adaxial face, thinning at the margins and on the abaxial face in correspondence of the midrib. The spongy tissue is no chlorenchymatous and occupies the central part of the leaf wrapping the vascular bundles. There are three main vascular bundles, of which the larger one is placed in correspondence of the midrib and two smaller ones at the margins. Other small vascular bundles (six for each side) are distributed among the mian three. In particular, the three largest vascular bundles, which like all the others have the phloem toward the abaxial face, are surrounded externally by a crescent-shaped calotte of sclerenchymatous fibres. Moreover, a sheath of large cells containing drusen of calcium oxalate is set along the outer surface of the calotte. This anatomical structure is very similar to that concerning the leaves of D. busambrae. Main differences concerning: the smaller size in $D$. borbonicus, with a shape almost flat with an angle of ca. $170^{\circ}-180^{\circ}$, midrib little protruding, the vascular bundle corresponding much smaller, a more developed palisade (usually 3-layered) and not more than six secondary vascular bundles for each side. On the contrary, D. busambrae is characterized by larger leaves, canaliculate with an angle of ca. $140^{\circ}$, midrib much more developed and protruding, the vascular bundle corresponding much larger with diameter almost double, the palisade less developed (usually 2-layered) and 7-8 secondary vascular bundles per side (Fig. 4B). Much more remarkable differences can be observed in the leaves of $D$. borbonicus if they are compared woth those of $D$. minae. This latter species shows leaves less wide and very thick, canaliculate with an angle of $135^{\circ}-140^{\circ}$, main vascular bundles with a diameter more than twice and the vascular bundles of the second order less numerous (3-5 per side), epidermis with larger cells and thicker cuticle, spongy tissue wider (Fig. 4C). Overall, D. minae seems to be more closely related to D. arrosti C.Presl (1822: 60) (Fig. 4D). Actually, the two species show remarkable similarities in the leaf shape and tissue arrangement, even if significant structural differences can be observed, such as the leaf thickness and outline, distribution and size of the palisade and spongy tissues, and number of the second order vascular bundles.

Etymology:-The epithet refers to the Bourbon Royal Family (in Latin "Borbonicus"), who had a game reserve and a Royal Palace in Ficuzza, (near Palermo) where the new species grows.

Phenology:-Flowering late May-early June; fruiting late June-July.

Habitat and distribution:-Dianthus borbonicus is a very rare chasmophyte localized on Mesozoic northfacing limestones of a rocky walls at 1100-1150 m a.s.l. (Fig. 2A). On the basis of our field investigations, it grows exclusively on a rocky outcrop near Pizzo Morabito at the forested area of Ficuzza (Palermo Province, North-Western Sicily). It is interesting to note that other rare endemics occur, such as Anthemis cupaniana Todaro ex Nyman (1879: 360), Centaurea busambarensis Gussone (1845: 873), Helichrysum pendulum (C.Presl 1822: 97) C.Presl (1826: 29), and Athamanta sicula Linnaeus (1753: 244).

Conservation status:-Only one site is currently known for Dianthus borbonicus (the Ficuzza-Rocca Busambra Natural Reserve, Fig. 5). Despite the population is small, being represented by about 100 individuals, which occupy an area of about $10.000 \mathrm{mq}$, it does not seem that it are seriously threated by human activities. Furthermore, considering the remarkable conservativeness of the rupestrian environments and the long life span of the plant, only occasional events (such as fires), may cause a decreasing of the number of mature individuals. According to the criterion "D". we propose to consider this species as "Endangered" and to include it, for its rarity and punctiform distribution, into the category EN D (IUCN 2014).

Discussion:-Dianthus is one of the most critical genera in Caryophyllaceae Juss., being represented by several and poorly investigated groups. From the morphological point of view, important characteristics concern the shape of calyx, calyx, epicalyx scales and corolla (Bacchetta et al. 2004, 2010). Based on these features, D. borbonicus has to be included into the $D$. sylvestris group, which shows a high diversity in the central Mediterranean area. The new species seems to be closely related to D. cyathophorus Moris (1852: 32) from Sardinia, with which it shares the epycalyx scales markedly divaricate, morphological feature rather unusual in Dianthus. However, D. cyathophorus differs from $D$. borbonicus in having a larger size $(40-70 \mathrm{~cm}$ tall), flat leaves, $10-25 \mathrm{~cm}$ long, epicalyx scales with mucro 3-4 mm long, calyx 22-25 mm, petals 30-35 mm long, with limb 9-10 $\mathrm{mm}$ wide and anthers $4 \mathrm{~mm}$ long (Fig. 6A3-D3). A further similar species is D. minae, which was described from northern Sicily (Mts. Madonie). Due to its remarkable morphological similarity, D. minae was previously considered by Bacchetta et al (2010) a synonym of $D$. cyathophorus, but ongoing field investigations revealed that they are two well distinct species (features concerning the shape and size of leaves, epicalyx scales, calyx, petals and anthers, see Table 2). D. borbonicus shows significant 
differences in comparison with both D. cyathophorus and D. miniae, since its compact woody stock, shorter stems and leaves, different shape and size of the epicalyx scales, longer petals and shorter anthers. In particular, D. borbonicus differs from $D$. minae also in other features, such as leaves more or less flat not canaliculate, few-flowered stems (1-4), epicalyx scales larger and usually subrounded, calyx with a greater diameter, petals longer and wider, with teeth much more numerous (Fig. 6A2-D2). The phenology, leaf anatomy and seed testa sculptures represent further differences. In fact, $D$. minae is an early flowering species (from early May to early June), with leaves anatomically very different from those ones of $D$. borbonicus, but very similar to those of $D$. arrosti, and seed coat with anticlinal walls formed by deep and very narrow grooves, not trabeculate. On the contrary, the suffruticose habit, well developed calyx, shortly mucronate epicalyx scales and a very similar leaf anatomy of $D$. borbonicus make the latter species more similar to $D$. busambrae, a chasmophyte localized on the rupestrian stands of the neighbouring Rocca Busambra. Actually, it has to be emphasized that the morphological differences between the two species are quite remarkable. They are mainly concerning the woody stock very loose with more developed stems, leaf canaliculate and longer, epicalyx scales appressed and transversally elliptical, calyx teeth overlapping, petals very shorter, cuneate, with limb narrower and having few teeth, anthers and ovary shorter in D. busambrae (Fig. 6A4-D4). Furthermore, the latter is characterized a later flowering period (mid June to July), by relevant differences in the leaf anatomy and seed coat, which are characterized by anticlinal walls with deep and narrow grooves, not trabeculate, with $U$ - or $\Omega$-like undulations.

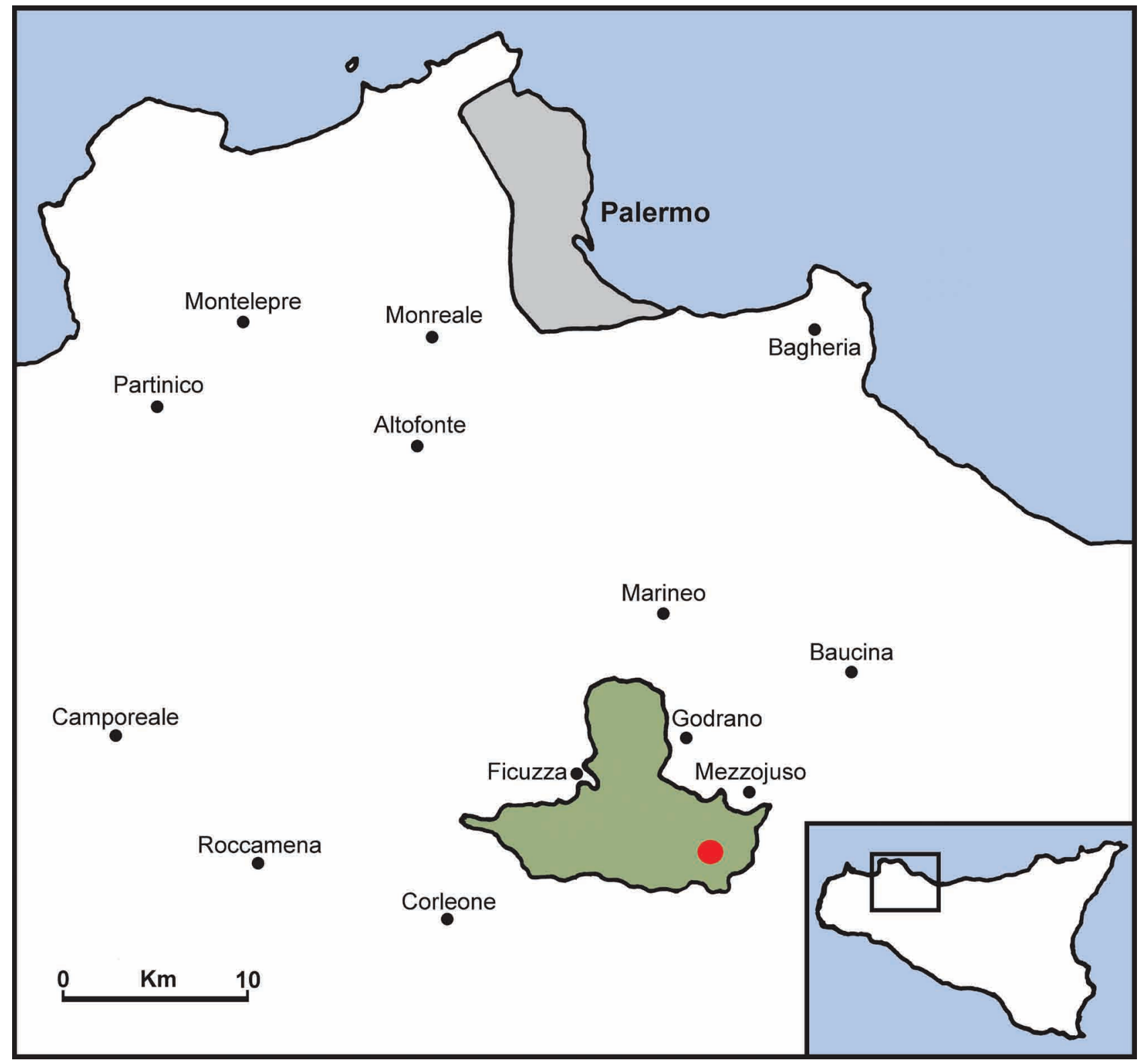

FIGURE 5. Geographical distribution of Dianthus borbonicus (red dot). Ficuzza-Rocca Busambra Natural Reserve (green area). 


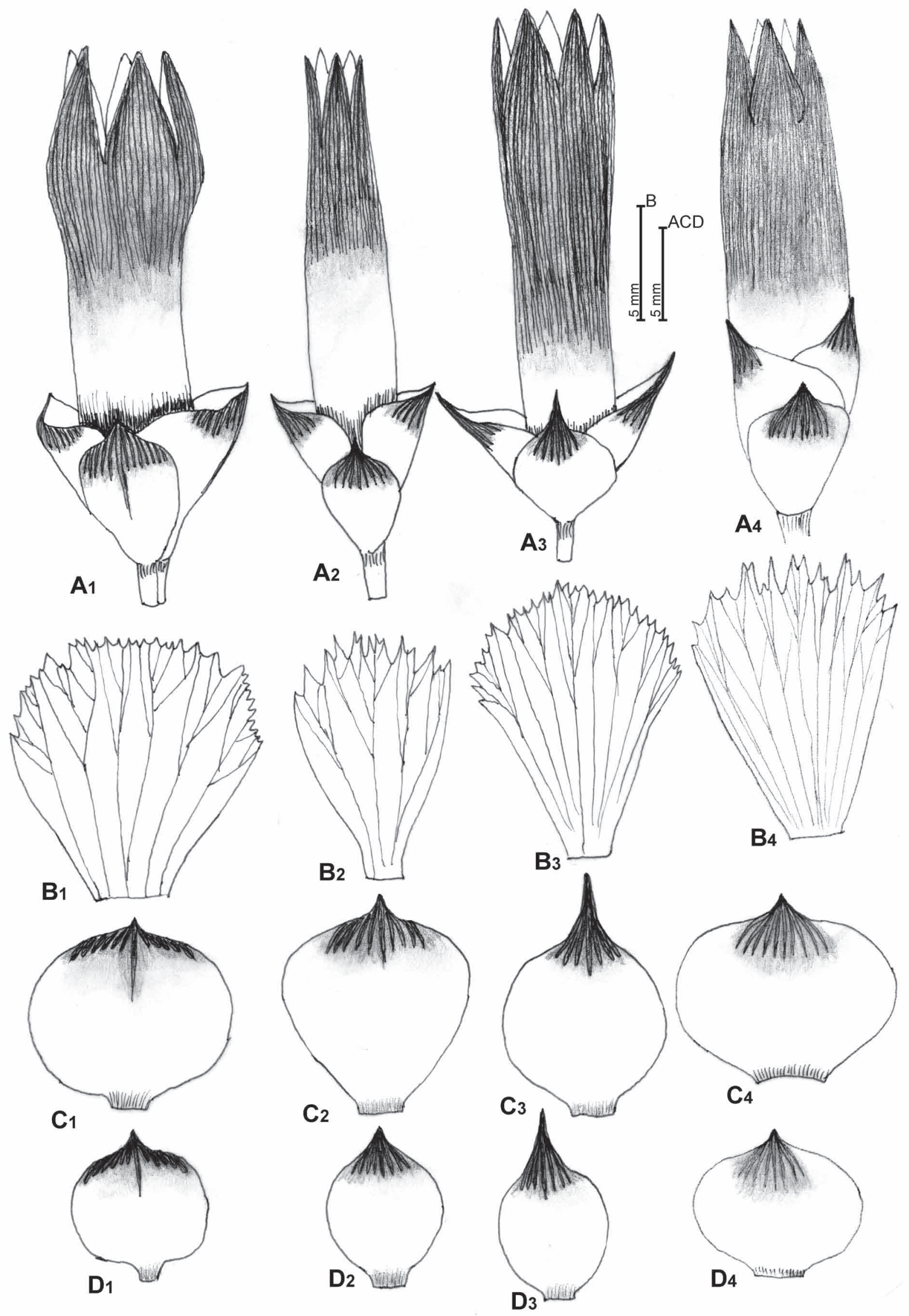

FIGURE 6. Calyces (A), petal limbs (B), inner (C) and outer epicalyx scales 1 (D) of Dianthus borbonicus (1), D. minae (2), D. cyathophorus (3) and D. busambrae (4) (drawing by S. Brullo based on living material coming from the type localities). 
Additional specimen examined (paratype):-SICILY. Ficuzza, Corona 1 del Re presso Pizzo Morabito, su pareti calcaree esposte a Nord, a ca. 1150 m. di altitudine, 29 June 2011, Brullo, Colombo, Perrone \& Ilardi s.n. (CAT!).

TABLE 2. Main differential characters of Dianthus borbonicus and allied species

\begin{tabular}{|c|c|c|c|c|}
\hline Characters & D. borbonicus & D. cyatophorus & D. minae & D. busambrae \\
\hline Plant size (cm) & $15-30(35)$ & $(20) 40-70$ & $50-70$ & $(15) 30-60$ \\
\hline Woody stock & compact & loose & loose & loose \\
\hline Branch length (cm) & $1-4$ & $2-7(10)$ & $3-10$ & $3-10$ \\
\hline Leaf shape & flat & flat & canaliculate & canaliculate \\
\hline Leaf length (cm) & $2-10(11)$ & $10-25$ & $4-18$ & $3-16$ \\
\hline Leaf width (mm) & $2-4$ & $1.5-3$ & $2-4$ & $2-3(4)$ \\
\hline Number of flowers per stem & $1-4$ & $2-5(6)$ & $2-8$ & (1) $2-5$ \\
\hline Epycalyx scales arrangement & divaricate & divaricate & divaricate & appressed \\
\hline Epycalyx scales mucro length (mm) & $0.5-2$ & $3-4$ & $0.7-1$ & $1-1.3$ \\
\hline Outer scale shape & $\begin{array}{l}\text { ovate to } \\
\text { subrounded }\end{array}$ & obovate & elliptical & transversally elliptical \\
\hline Outer scale length (mm) & $8-10$ & $9-10$ & $5.5-8$ & $7-8.5$ \\
\hline Outer scale width (mm) & $5-7.5$ & $6-6.5$ & $5-6$ & $7-10$ \\
\hline Inner scale shape & $\begin{array}{l}\text { subrounded to } \\
\text { obovate }\end{array}$ & subrounded & obovate & transversally elliptical \\
\hline Inner scale length (mm) & 10 & $10-12$ & $8-9$ & $9-10$ \\
\hline Inner scale width (mm) & $12-13$ & $9-11$ & $8-9$ & $9-13$ \\
\hline Calyx length (mm) & $26-30$ & $22-25$ & $28-32$ & $26-30$ \\
\hline Calyx teeth length (mm) & $6-7$ & $6-6.5$ & $5-6$ & $6-7.5$ \\
\hline Petal length (mm) & $40-45$ & $30-35$ & $34-40$ & $25-30$ \\
\hline Petal limb shape & cuneate & cuneate & cuneate-rounded & cuneate \\
\hline Petal limb width (mm) & $11-14$ & $9-10$ & $8-9$ & $8-9$ \\
\hline Petal teeth number & $20-34$ & $20-30$ & $11-13$ & $9-15$ \\
\hline Petal teeth length (mm) & $0.3-2$ & $0.3-1$ & $0.8-1.5$ & $0.7-2.5$ \\
\hline Anther length (mm) & 3.5 & 4 & $5-5.5$ & $2.6-2.8$ \\
\hline Ovary length (mm) & $8-10$ & $8-9$ & $8.5-9$ & 6 \\
\hline
\end{tabular}

\section{Diagnostic key to the species of the Dianthus sylvestris group occurring in Sicily:}

1. Epicalyx scales always divaricate 2 Epicalyx scales appressed to the calyx

2. Stems $15-30(-35) \mathrm{cm}$ long, outer scales $8-10 \mathrm{~mm}$ long, petal 40-45 $\mathrm{mm}$ long, with limb $11-14 \mathrm{~mm}$ wide, anthers $3.5 \mathrm{~mm}$ long. ..D. borbonicus Stems 50-70 cm long, outer scales 5.5-8 mm long, petal 34-40 mm long, with limb 8-9 mm wide, anthers 5.0-5.5 mm long......

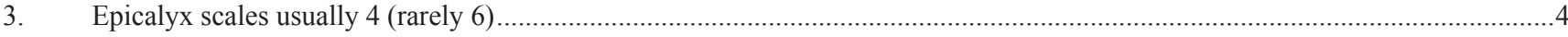

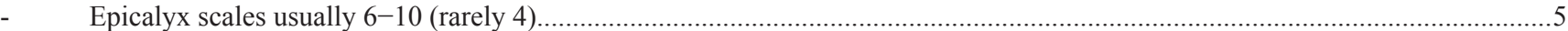

4. Woody stock loose, with branches 3-10 cm long, petal 25-30 mm long, with limb 8-9 mm wide ........................ busambrae

- $\quad$ Woody stock contracted, with branches $0.5-1.0 \mathrm{~cm}$ long, petal 38-40 mm long, with limb $12-14 \mathrm{~mm}$ long..................

5. Woody stock contracted with leaves $1.0-4.5 \mathrm{~mm}$ long, stems 2-8-flowered, outer scales 5.0-7.5 mm long, ovary 9-10 mm long. D. siculus 
6. Outer scales lanceolate 2-3 mm wide, inner scales ovate-lanceolate 6-7 mm wide, petal 35-40 mm long, with limb 9-10 mm wide, anthers $3 \mathrm{~mm}$ long D. gasparrinii Outer scales obovate $3.0-3.5 \mathrm{~mm}$ wide, inner scales obovate $8.0-8.5 \mathrm{~mm}$ wide, petal $26-33 \mathrm{~mm}$ long, with limb 6-8 mm wide, anthers $3.5 \mathrm{~mm}$ long... D. graminifolius

\section{Acknowledgements}

The authors are very grateful to Dr. Girolamo Fichera from the University of Catania for his useful collaboration and technical assistance for the seed coat analyses.

\section{References}

Bacchetta, G., Brullo, S., Casti, M. \& Giusso del Galdo, G. (2004) Contributo alla sistematica delle popolazioni appartenenti al ciclo di Dianthus sylvestris Wulfen presenti in Sardegna, Sicilia e Italia meridionale. Informatore Botanico Italiano 36 (1): 160-161.

Bacchetta, G., Brullo, S., Casti, M. \& Giusso del Galdo, G. (2010) Taxonomic revision of the Dianthus sylvestris group (Caryophyllaceae) in central southern Italy, Sicily and Sardinia. Nordic Journal of Botany 28: 137-173.

http://dx.doi.org/10.1111/j.1756-1051.2009.00459.x

Barthlott, W. (1981) Epidermal and seed surface character of plants: Systematic applicability and some evolutionary aspects. Nordic Journal of Botany 1: 345-355.

http://dx.doi.org/10.1111/j.1756-1051.1981.tb00704.x

Beccari, N. \& Mazzi, V. (1966) Manuale di tecnica microscopica. Società Editrice Libraria, Milano, 366 pp.

Gontcharova, S.B., Gontcharov, A.A., Yakubov, V.V. \& Kondo, K. (2009) Seed surface morphology in some representatives of the genus Rhodiola sect. Rhodiola (Crassulaceae) in the Russian Far East. Flora 204: 17-24.

http://dx.doi.org/10.1016/j.flora.2008.01.009

Gussone, G. (1845) Florae Siculae Synopsis, vol. 2 (2). Typis Tramater, Neapoli, 251 pp.

Hamzaoğlu, E., Koç, M. \& Askoy, A. (2015a) Dianthus aticii, a new species from Turkey (Caryophyllaceae). PhytoKeys 48: 21-28. http://dx.doi.org/10.3897/phytokeys.48.4446

Hamzaoğlu, E., Koç, Büyük, I., Askoy, A. \& Aydin, S.S. (2015b) Presence of Dianthus roseoluteus Velen. (Caryophyllaceae) in Turkey and a new species: Dianthus macroflorus Hamzaoğlu. Systematic Botany 40: 208-213.

http://dx.doi.org/10.1600/036364415X686512

İlçim, A., Behçet, L. \& Mükemre, M. (2013) Dianthus vanensis (Caryophyllaceae), a new species from Turkey. Turkish Journal of Botany 37: 219-224.

IUCN (2014) Guidelines for Using the IUCN Red List Categories and Criteria. Version 11. Prepared by the Standards and Petitions Subcommittee, Cambridge U.K. Available from: http://jr.iucnredlist.org/documents/RedListGuidelines.pdf (accessed 10 October 2014)

Jacquin, N.J. (1787) Collectanea ad Botanicam, Chemiam et Historiam naturalem spectantia, vol. 1. Officina Wappleriana, Vindobonae, $386 \mathrm{pp}$.

Linnaeus, C. (1753) Species Plantarum, vol. 1. Laurentii Salvii, Stockholm, 560 pp.

Mazzola, P., Raimondo, F.M. \& Ilardi, V. (2004) Dianthus minae (Caryophyllaceae), a new species from the Madonie Mountains (NSicily). Bocconea 17: 307-312.

Moris, G.G. (1852) Enumeratio seminum Regii Horti Bot. Taurinensis. anno 1852. Regio Typographeo, Augustae Taurinorum.

Nyman, C.F. (1879) Conspectus florae Europaeae, vol. 2. Officinae Bohlinianae, Örebro, 252 pp.

Presl, C.B. (1822) Plantarum rariorum siciliae aliarumque minus cognitarum, diagnoses et descriptiones. In: Presl, C.B. \& Presl, J.S. (Eds.) Deliciae Pragenses. Calve, Pragae, pp. 3-152.

Presl, C.B. (1826) Flora Sicula, 1. A. Borrosch, Pragae, 217 pp.

Sass, J.E.(1958) Botanical microtecnique, ed. 3. Jowa State College Press, Ames, 228 pp.

Soldano, A. \& Conti, F. (2005) Dianthus busambrae. In: Conti, F., Abbate, G., Alessandrini, A. \& Blasi, C. (Eds.) An annotated checklist of the Italian vascular flora. Palombi Editore, Roma, $28 \mathrm{pp}$.

Stork, A.L., Snogerup, S. \& Wuest, J. (1980) Seed characters in Brassica section Brassica and some related groups. Candollea 35: 421-450.

Thiers, B. (2015) Index herbariorum, a global directory of public herbaria and associated staff. New York Botanical Garden's Virtual 
Herbarium. Available from http://sweetgum.nybg.org/ih/ (accessed 26 August 2015)

Vural, C. (2008) A new species of Dianthus (Caryophyllaceae) from Mount Erciyes, Central Anatolia, Turkey. Botanical Journal of Linnean Society 158: 55-61. http://dx.doi.org/10.1111/j.1095-8339.2008.00843.x

Yildiz, K. (2002) Seed morphology of Caryophyllaceae species from Turkey (North Anatolia). Pakistan Journal of Botany 34 (2): $161-171$.

Yildiz, K. \& Güzel, S. (2008) Morphological investigation of some North Cyprus endemics. International Journal of Natural and Engineering Sciences 2 (3): 85-91. 